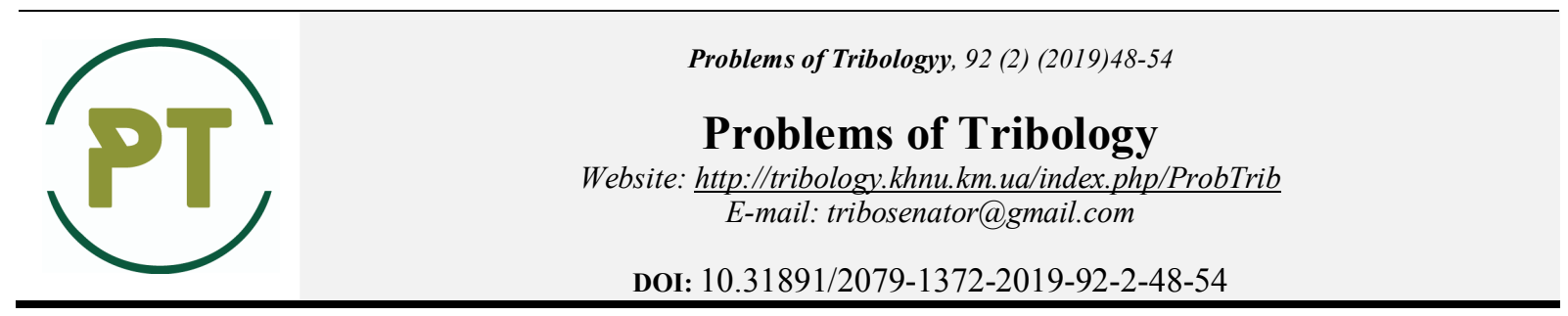

\title{
Estimation of tribotechnical characteristics and signals of acoustic emission for a friction pair of steel 30HGSA and duraluminium D16 modified by an alloy VK8
}

\author{
O.A. Mikosianchyk ${ }^{1 *}$, V.V. Tokaruk ${ }^{1}$, R.G. Mnatsakanov ${ }^{1}$ \\ ${ }^{1}$ National Aviation University, Kyiv, Ukraine \\ *E-mail: oksana.mikos@ukr.net
}

\begin{abstract}
Application of the method of acoustic emission to study the processes of structural adaptability in friction under conditions of slip for the tribosystem of steel 30HGSA and duraluminium D16, on the surface of which the method of electroscope alloying is applied an alloy BK8 followed by surface processing by superficial plastic deformation. The formation of wear-resistant secondary structures has been established by increasing the intensity of heat emission in the frictional contact, which leads to an increase in the mechano-chemical activation of the surface layers of the metal. The modification of dyuraluminium D16 by the electrospray coating BK8 provides a reduction of the average power of acoustic emission by 2 times during the wear-in stage by reducing the stress-strain state of the surface layers and reducing the ability of the material BK 8 to absorb mechanical energy during deformation. The correlation dependence of the total weight wear of friction pairs and the average power of acoustic emission is established. bility.

Keywords: Acoustic emission, wear, D16 duralumin, alloys BK8, electrospray doping, structural adapta-

\section{Problem statement}

Improving the quality, reliability, efficiency and performance of machinery, tools, equipment and other mechanical engineering products, reducing their relative material consumption and energy consumption are achieved first of all by the usage of materials and progressive strengthening technologies, which allow to increase strength, wear resistance, corrosion resistance and other physical and mechanical properties of machine and instrument parts. It is of great importance to reduce the relative material consumption of products by replacing ferrous metals with lighter colored ones, in particular aluminum and its alloys. However, the expansion for practical use of aluminum alloys for the manufacture of parts and various friction pairs impedes the failure to meet the high technological requirements of its operational characteristics, such as insufficient hardness and low wear resistance. The elimination of these disadvantages associated with improvement of the composition and quality of the surface layers of products by applying modern methods of modifying the surface layers, which increase their wear resistance. An important step here is the choice of a methodology for controlling of the tribotechnical parameters of the friction pair during the testing phase. The paper proposes to use acoustic emission analysis (AE), which is an effective diagnostic method in modern tribo-monitoring.
\end{abstract}

\section{Literature review}

Many of experimental studies have been conducted to examine the relationship between the AE parameters and the wear resistance of the friction pairs.

The paper [1] develops a theoretical model to correlate acoustic emissions to sliding friction based on elastic asperity contact of materials. It is found that sliding speed, load supported by asperities, the number of asperity contact and surface topographic characteristics influence the energy of AE signal. With the help of this model it is possible to estimate the contact load supported by asperities from AE measurement, which is a critical parameter to evaluate lubrication conditions in engineering applications.

Measurements of acoustic emission in severe sliding of metallic specimens were performed with a view to determining relationships between $\mathrm{AE}$ and wear-friction parameters [2]. It was found that $\mathrm{AE}$ is readily observed in dry sliding and that emission rates and cumulative count data are sensitive to the external variables 
which influence tribological contact conditions. A relationship between cumulative AE count and frictional work is proposed.

The results revealed a good correlation between the friction coefficient and acoustic emission rms voltage for dry sliding [3]. Such a relationship may allow the prediction of a reasonable friction coefficient $\mu$ from an AE signal. It was also determined that the friction work correlated well with the corresponding integrated AE voltage over time, intRMS. The detection of the sliding speed threshold beyond which accelerated wear would occur was possible from the intRMS variation. Proportionality between the theoretically determined grease film thickness and the intRMS was observed.

Duraluminium is widely used in many industrial areas, especially in aviation. D16 alloy in the form of sheets and pressed intermediate products is the main material for the power elements of the aircraft design (frame parts, sheathing, clamping elements, rivets, spokes, control drawbars) and other loaded structures [4]. Surface doping of aluminum alloys using laser heat up to melting allows to change the chemical composition of the surface layers, and consequently, also the physical and mechanical properties in a wide range [5]. Based on an extensive experimental material, the technology of surface hardening of aluminum alloys through doping with laser heating has been developed: power $1,0 \mathrm{~kW}$; processing speed $12.5 \mathrm{~mm} / \mathrm{s}$; doping thickness $0.3 \mathrm{~mm}$. Within the production conditions the details of the D16 and AJ125 alloys were processed according to the proposed technology. The production tests of the processed parts demonstrated that that their durability increased in $1.5 \ldots 2$ times due to increased surface hardness (up to $6000 \mathrm{MPa}$ ) and wear resistance.

In [6], it was found that on aluminum alloys with the help of electrospark alloying (ESA) with Al-Sn alloy electrodes, a wear-resistant coating can be obtained, which is 5-6 times higher than the resistance of hardened steel. A feature in this coating is the presence in its structure of micro- and nano- fibers of tin oxide, which have a high microhardness of HV $1200 \mathrm{~kg} / \mathrm{mm}^{2}$.

The possibility of using aluminum parts, hardened by MAO (microarc oxidation), to work in difficult tribological conditions is shown. Apart from the multiple increase in wear resistance and time to failure, the use of aluminum alloys with MAO coatings relieve friction (almost 3 times), which significantly improves the dynamic characteristics of the nodes [7].

Thus, a promising area in improving the wear resistance of aluminum alloys is their surface hardening. At the same time, the important point is the choice of hardening method, which is determined by both economic and technological requirements. It is more economically beneficial to apply microplasma-spark methods, including ESA, in the conditions of small- and medium-scale productions.

\section{Purpose of the study}

Determination of efficiency of application of AE method for research of processes of structural adaptability of contact surfaces with friction.

\section{Methodology}

Tribological research of friction and wear of contact surfaces were carried out on a serial friction machine 2070 SMT-1 for 240 minutes in the mode of boundary lubrication with an oil consumption of 1.2 liters per hour.

Model ring samples of friction pairs are made of 30HGSA steel and dyuraluminium D16, on the surface of which the ESA method is used to apply VK8 alloy. Electrospark doping was carried out on the standard industrial installation "Elitron 22A" [8] in the air at a specific length of surface treatment of the sample - 1 $\mathrm{min} / \mathrm{cm}^{2}$. The duration of electrical pulses was $200 \mu \mathrm{s}$. To obtain evenly strengthened layers of required roughness and density, further surface processing was performed through surface plastic deformation, resulting in roughness of $0.5 \mu \mathrm{m}$. One of the samples rotates with a frequency of $400 \mathrm{~min}^{-1}$, the other (fixed) sets the coaxial with pressing face surfaces to each other with an axial load of $600 \mathrm{~N}$. The investigation of contact surfaces was carried out according to the following scheme: in the friction pair D16+VK8 - 30HGSA the moving element was a sample of duraluminium D16, which surface was strengthened by the alloy BK8; in a friction pair 30 HGSA - D16+VK8 a moving element was a model of steel 30HGSA. As a lubricant, engine oil $\mathrm{M}_{10 \mathrm{G}_{2} \mathrm{k}}$ (State Standard Spesification-8581-78) was used.

During the experiment, the simultaneous registration of the moment, friction, average temperature of the surface of the tribological contact as well as the registration of acoustic emission parameters (AE) was performed. As an information characteristic of the AE for the study of the dynamics of the formation and destruction of secondary structures, the average power of the AE signal was selected proportional to the value of the wear rate (the magnitude of the averaging was $20 \mathrm{msec}$ ) [9]. The method of processing signals of acoustic emission during friction and wear and measuring the intensity of wear using the AE method is described in [10]. This technique allows evaluating the intensity of wear of contact surfaces.

\section{Analysis of findings}

The test results of the friction pair D16+VK8 - 30HGSA for wear resistance at constant load P $=600 \mathrm{~N}$ showed normal operation of the tribosystem throughout the entire observation period. 
The analysis of the change in the antifriction properties of the tribological contact in time showed that the burn-in time recorded after the change in the friction coefficient for the tribosystem D16+VK $8-30$ HGSA was about 20 minutes. At the same time, up to 12 minutes of testing, an increase in this parameter to the level of $f=$ 0.19 was recorded; further, its gradual decrease to the level of $f=0.17$ was observed. During the run-in, there was an increase in the average temperature in the tribological contact zone to $45^{\circ} \mathrm{C}$. At the same time, after the end of the running-in period, at the stage of a stable tribosystem, the average temperature in the tribological contact zone continued to grow, but the average temperature slowed down by an average 4 times (Fig. 1).

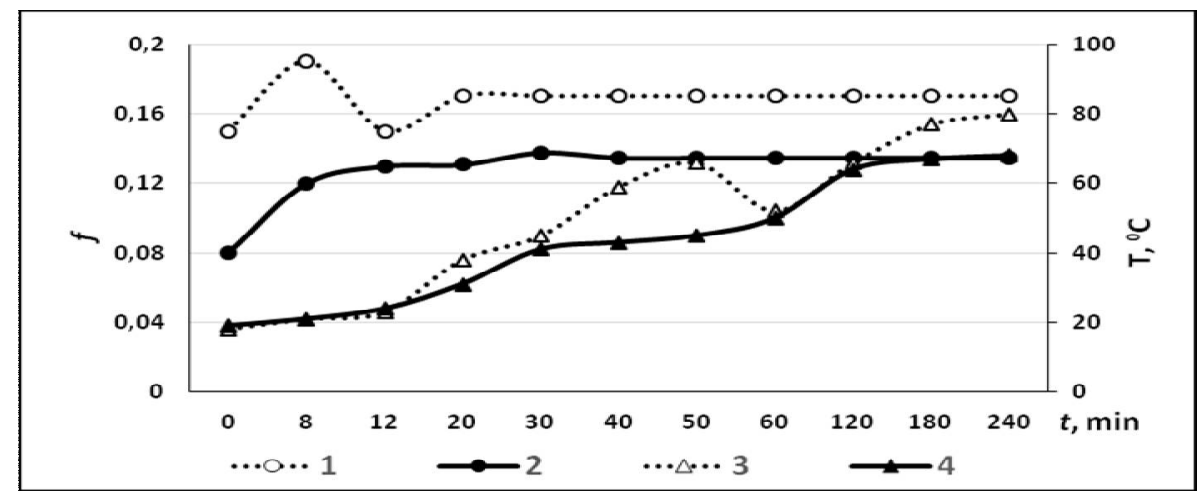

Fig.1. The kinetics of changes in the friction coefficient and temperature in the contact zone of friction pairs during performance: for a pair of D16+VK8 - 30HGSA - 1 - coefficient of friction, 3 - temperature; for a pair of 30HGSA - D16+VK8 - 2 friction coefficient, 4 - temperature.

The nature of the change in the average acoustic emission power during the entire observation period is shown in Fig. 2. A more detailed analysis of the change in acousto-emission radiation over time for the D16+VK8 - 30HGSA tribosystem in the area of constant wear over the interval $3000 \mathrm{~s}-3500 \mathrm{~s}$ tests is shown in Fig. 3.

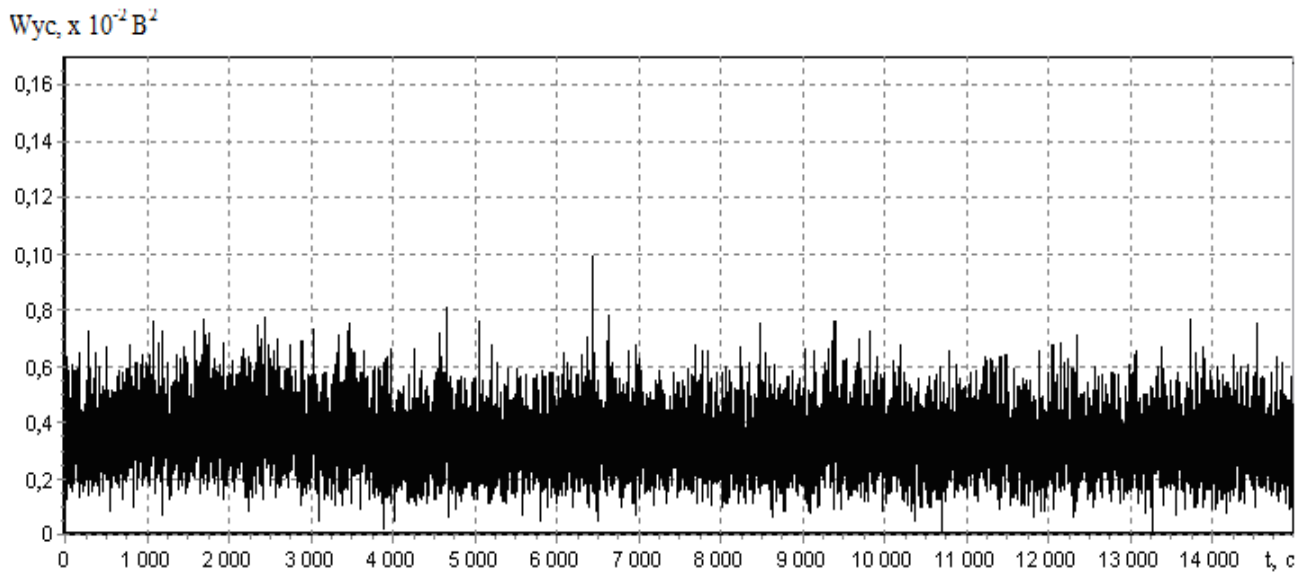

Fig. 2. The nature of the change in the averaged power of the AE signals over time (seconds) for the D16+VK8 - 30HGSA tribosystem.

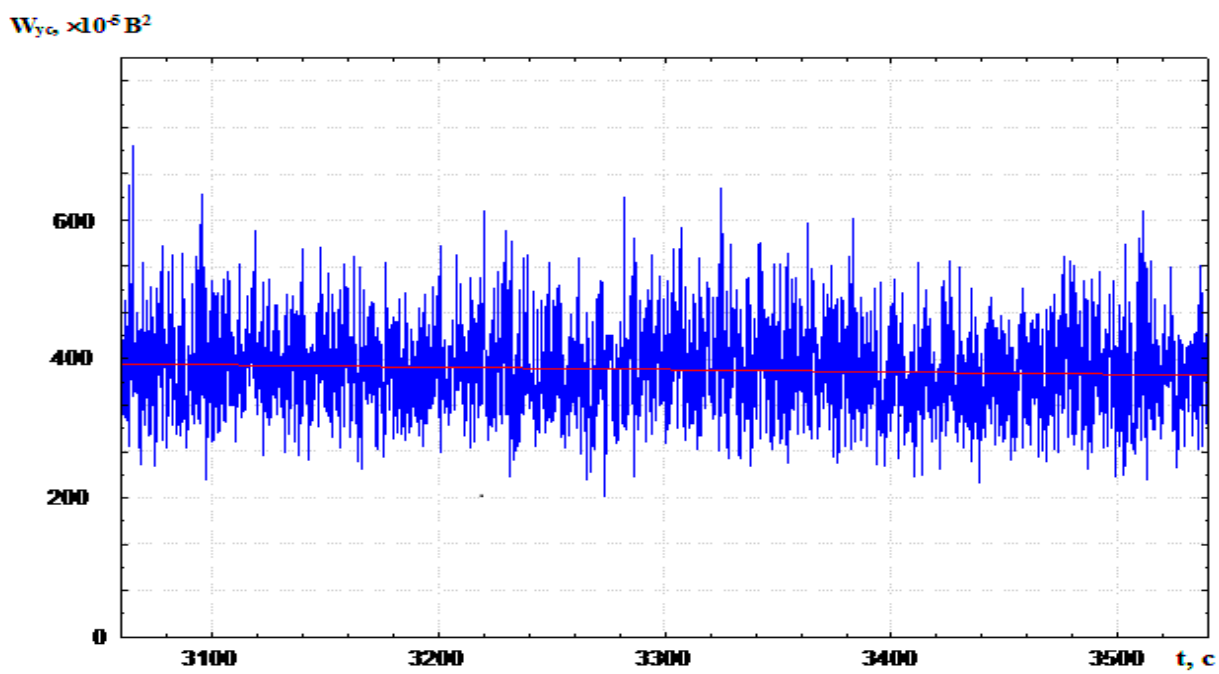

Fig. 3. The change in the averaged power of the AE signals over time (seconds), the tribosystem D16+VK8 - 30HGSA. 
Statistical analysis of the change in acousto-emission radiation over time showed that during the selected time period the histogram of the distribution of the averaged power of the AE has a normal distribution pattern (Fig. 4) and remains the same both at the stage of wear-in of the triboelements and at the stage permanent work of friction pairs. At the same time, according to the normal distribution law, the mathematical expectation of the parameter of the averaged power of AE signals is Wyc. $\approx(380-420) \cdot 10^{-5} \mathrm{~B}^{2}$, the average deviation is $75 \cdot 10^{-5} \mathrm{~B}^{2}$.

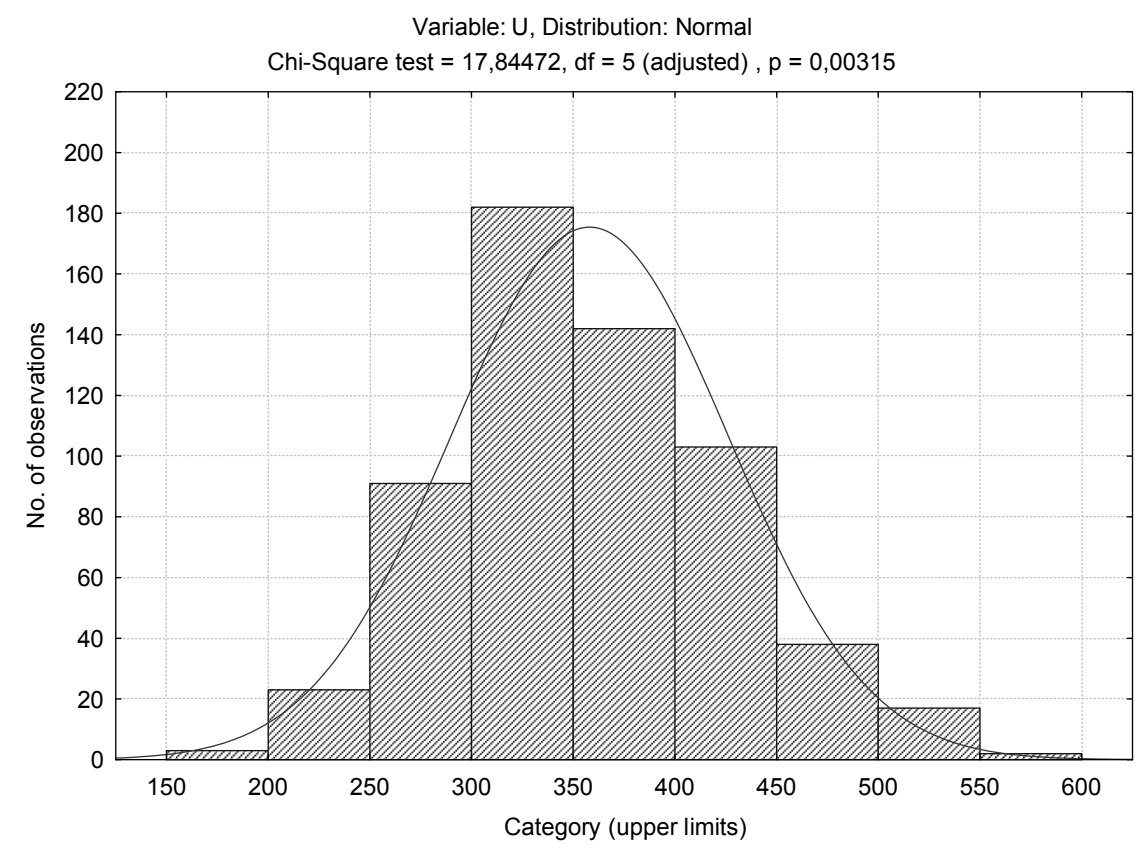

Fig. 4. The histogram of the distribution of the averaged power of AE signals of the D16 + VK8 tribosystem according to the normal law (for an operating interval of 3000-3500 s).

The results of testing the tribosystem $30 \mathrm{HGSA}-\mathrm{D} 16+\mathrm{VK} 8$ also showed normal performance with the application of a load of $\mathrm{P}=600 \mathrm{~N}$.

Analysis of changes in the average surface temperature in the zone of tribological contact in time (Fig. 1) revealed three characteristic areas of $0-24 \mathrm{~min}, 24-120 \mathrm{~min}$ and $120-240 \mathrm{~min}$. At the same time, the running-in period of the tribosystem is $0-24$ minutes characterized by a significant increase in the average surface temperature in the zone of tribological contact from 19 to $43^{\circ} \mathrm{C}$. The period of $24-120$ minutes is characterized by a decrease in the growth rate of the average surface temperature in the tribological contact zone from $43^{\circ} \mathrm{C}$ to $67^{\circ} \mathrm{C}$. Subsequently, the average surface temperature in the tribological contact zone remains almost constant at $\approx 67-68^{\circ} \mathrm{C}$. Thus, it is possible to assume that in the tribological contact different rates of energy dissipation are appeared, which is released during friction of surfaces in frictional contact.

The friction coefficient at the end of the intake stage of the 30HGSA - D16+VK8 tribosystem remains constant and is equal to $f=0.135$, which is 1.3 times less than the average values of the friction coefficient for D16+VK8 - 30HGSA (Fig. 1). Thus, it was experimentally confirmed that the tribosystem 30HGSA D16+VK8 is characterized by better antifriction properties than the tribosystem D16+VK8 - 30HGSA.

Analysis of the mechanisms of energy dissipation in the tribological contact when applying a wearresistant coating BK-8 on the surface D16 demonstrates several things. First, the intensity of heat generation in frictional contact increases. For a friction pair D16+VK8 - 30HGSA, this parameter increases by 2 times, for a friction pair of 30HGSA - D16+VK8 - by 1.27 times, compared to reference samples [11]. Secondly, the $P e$ criterion for the friction pair D16+VK8 - 30HGSA increases by a factor of 2.46 after coating BK8. For the friction pair 30HGSA - D16+VK8, the criterion Pe does not change, since the calculations were carried out for a moving surface, in this case for steel $30 \mathrm{HGSA}$. It should be noted that the growth of the energy balance of the tribosystem as a whole leads to an increase in the wear resistance of the elements of tribological conjugation. Consequently, an increase in energy in the tribosystem, where the D16 surface of the modified BK8, during friction leads to an increase in the mechano-chemical activation of the surface layers of the metal, which leads to the formation of wear-resistant secondary structures.

The nature of the change in the averaged acoustic emission power over time for a friction pair 30HGSA D16+VK8 is shown in Fig. 5.

An analysis of the acoustic emission diagram when testing the 30HGSA - D16+VK8 tribosystem for durability showed the presence of some rare periodic bursts of averaged acoustic emission power of $250 \cdot 10^{-5} \mathrm{~B}^{2}$. However at all stages of the tribosystem's work $\mathrm{W}_{\mathrm{yc}} \approx(110-120) \cdot 10^{-5} \mathrm{~B}^{2}$. 


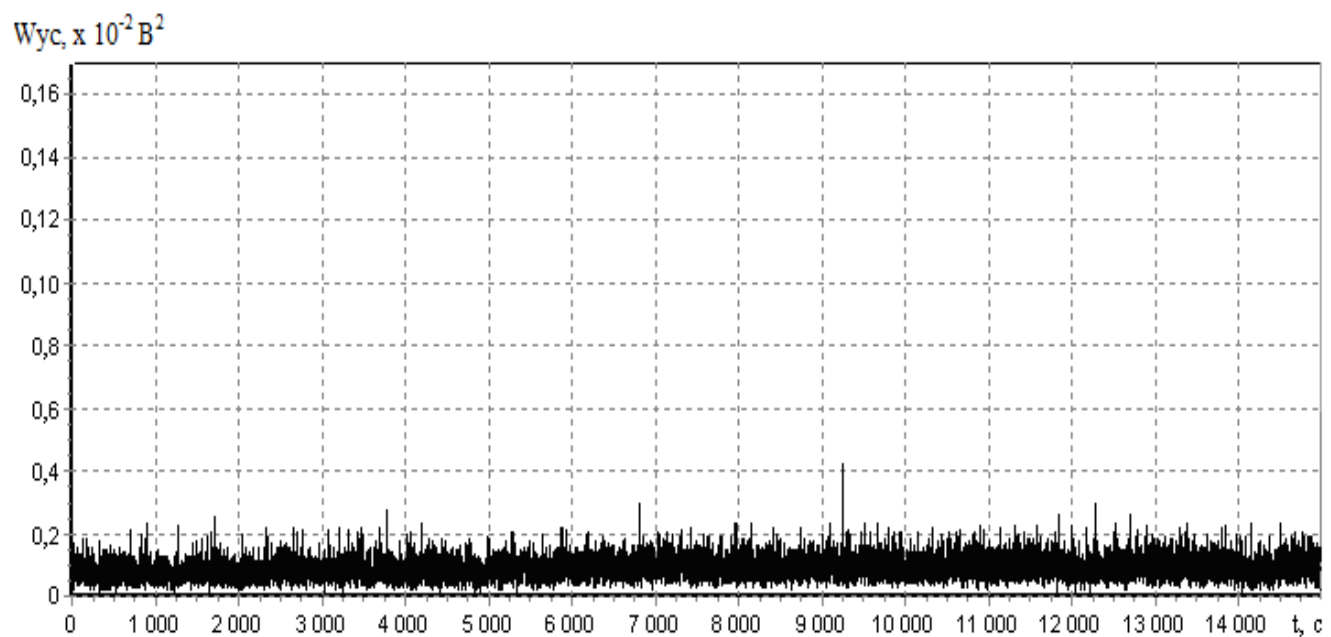

Fig. 5. The kinetics of changes in the average power of AE signals at the operating time for the tribosystem $30 \mathrm{HGSA}-$ D16+VK8.

A comparative analysis of the averaged power of the AE for reference samples and a friction pair when applying VK-8 coating on the D16 surface revealed the following patterns. First, the presence of a modified D16 surface with a VK8 coating provides stability to the $\mathrm{W}_{\mathrm{yc}}$ parameter both at the stage of running-in of contact surfaces (for friction pairs D16+VK8 - 30HGSA and 30HGSA - D16+VK8), and at the stage of further work with the triboelement. The decrease in the average power of the AE, on average by 2 times, at the stage of running-in indicates that the structural fitness of the triboelement occurs with less stress-deformed changes. The realization and manifestation of this mechanism contributes to an increase in the D16 surface hardness due to the deposition of the VK-8 alloy, which is characterized by high hardness $(\mathrm{HRC} \approx 87)$ due to tungsten carbides, by the method of electricspark alloying.

Secondly, at the stage of normal operability of the elements of tribological conjunction, the mode of $\mathrm{W}_{\mathrm{yc}}$ for a friction pair D16+VK8 - 30HGSA when coating VK8, an average of 2 times more, and for a friction pair $30 \mathrm{HGSA}-\mathrm{D} 16+\mathrm{VK} 8, \mathrm{~W}_{\mathrm{yc}}$ indicators are identical to reference samples. However, for both of the studied tribosystems with a modified duraluminium surface with VK8 coating, the single bursts of the parameter $\mathrm{W}_{\mathrm{yc}}$ exceeded the permanent characteristics by 1.5-2 times are observed. First of all, this is due to the increased friction power in the contact due to the increased background of internal friction due to increased internal stresses in the surface layers of the metal during friction while reducing the ability of the VK-8 material to absorb mechanical energy in the deformation process. The main reason is the low toughness of VK-8 alloy, which is $32 \mathrm{~kJ} / \mathrm{m}^{2}$, which, on average, is 10 times less than in reference alloy D16. Thus, the growth of the background internal friction may be due to an increase in the density of defects, which are brittle fracture concentrates, manifested in the detachment of oxidative films and is recorded by single bursts of the parameter of averaged AE power.

Analysis of the wear of the contact surfaces during friction. The reference samples are characterized by a large wear of the immovable triboelement: in the friction pair D16 - 30HGSA it is steel 30HGSA, in 30HGSA D16 -duraluminium D16.

When modifying the surface of duralumin D16 with an electrospark coating VK-8, firstly, the number of detachments on the surface of steel 30HGSA decreases. Secondly, a significant reduction in the weight wear of 30HGSA steel, as compared with the reference samples, was determined. When 30HGSA steel is used together with the modified D16+VK8 surface, its wear rate decreases by 15 and 5.8 times for friction pairs D16+VK8 30HGSA and 30HGSA - D16+VK8, respectively, the values of wear rate are $8,58 \cdot 10^{-7} \mathrm{~g} / \mathrm{min}$ (for the pair D16+VK8 - 30HGSA) and 5,64·10 $0^{-5} \mathrm{~g} / \mathrm{min}$ (for the pair 30HGSA - D16+VK8). Thirdly, the wear rate of the modified D16+VK8 surface is $1,98 \cdot 10^{-7} \mathrm{~g} / \mathrm{min}$ and $2,14 \cdot 10^{-6} \mathrm{~g} / \mathrm{min}$ for the D16+VK8 - 30HGSA and 30HGSA D16+VK8 pairs, respectively. The application of the VK8 hard alloy causes an increase in the wear rate of the modified surface for the D16+VK8 - 30HGSA pair by 4.6 times and a decrease in this parameter for the 30HGSA - D16+VK8 pair, on average, by 300 times.

The analysis of wear mechanisms of the studied contact surfaces. If to assume that the maximum wear rate in friction pairs happens during wear-in period, and with further development this parameter stabilizes and lays within the limits indicated above, then the average value of the averaged acoustic emission power :

$$
W_{y c}^{*}=\frac{W_{y c}^{\prime}+W_{y c}^{\prime /}}{2},
$$

where $W_{y c}^{\prime}$ is the average acoustic emission power during the period of wear-in of the contact surfaces; $W_{y c}^{\prime \prime}$ is the average acoustic emission power at the stage of stable operation of the elements of the tribosystem. 
There is a clear correlation between the total weight wear of friction pairs for the entire study period of operating time (240 minutes) on the parameter (Fig. 6).

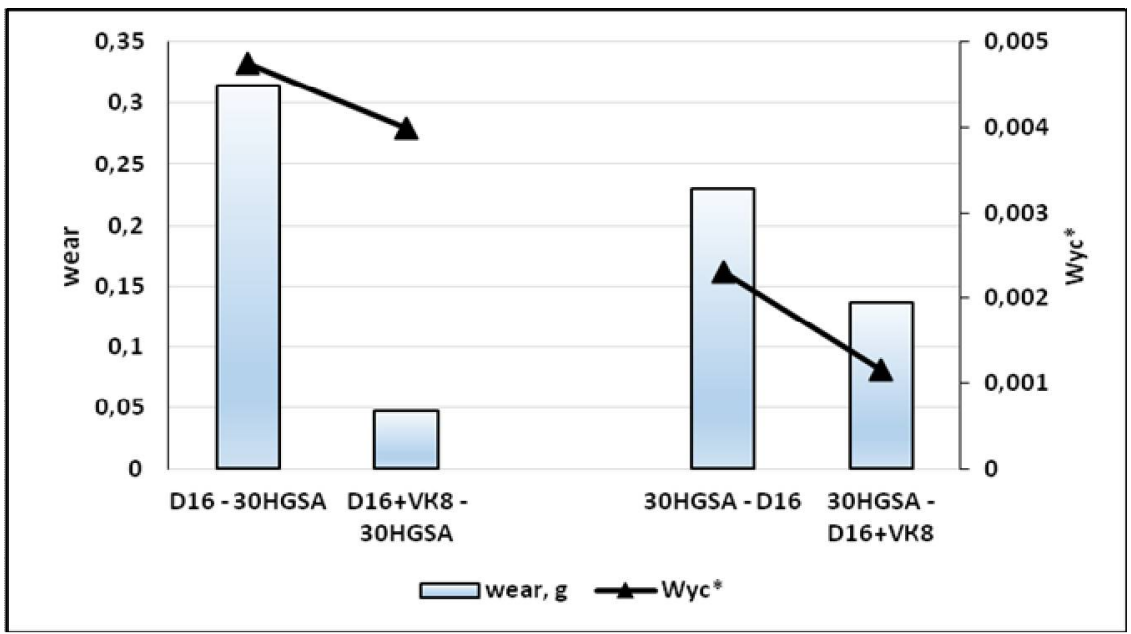

Fig. 6. The relationship of the parameter of the average acoustic emission power $W_{y c}^{*}$ and the weight wear of the contact surfaces during 240 minutes:

Modification of the surface layers of duralumin D16 due to the application of discrete electric-spark coatings reduces the stress-strain state under friction and ensures the acceleration of structural fitness. This is especially clearly manifested at the stage of burn-in of contact pairs, where the parameter of averaged power of AE is significantly reduced compared with reference samples. For coating VK8, an antifriction reduction was found, on average, 1.6-2 times, however, with an increase in the friction coefficient, the wear resistance of the contact surfaces does not decrease. On the contrary, the process of structural adaptability of the electrospark coatings under study is characterized by an increase in friction power, on average, by 1.27-2 times, which, in turn, causes an increase in temperature. Kostetsky B. equates the friction power indicator with the specific work of friction [12], which undoubtedly influences the processes of structural fitness of the elements of tribojet due to thermal activation during friction.

According to external indicators, secondary structures of type II are formed on the contact surfaces, characterized by heterogeneity - dominated by burnish areas covered with film, sometimes appear visible areas with a destroyed film. The destruction of the film indicates detachment of metastable secondary structures, which are oxides of non-stoichiometric composition. Chemical analysis of secondary structures on the reference sample D16 and modified D16+VK8 found that the oxygen concentration for these samples, respectively, is between 0.64 and $9.87 \%$, which indicates the active participation of oxygen in the formation of secondary structures on the activated contact surfaces with friction.

Thus, an increase in the structural-thermal activation of contact surfaces due to their modification by applying electricspark coatings in the process of friction leads to an intensification of mechanical and physicochemical processes under conditions of boundary lubrication, which, in general, increases the wear resistance of contact surfaces. The mechanism for increasing wear resistance is in the increase rate of physical and chemical processes that stipulate the formation of secondary structures with the participation of oxygen and activated molecules of lubricant.

\section{Conclusions}

1. The presence of a modified D16 surface with VK-8 coating, which is characterized by high hardness $(\mathrm{HRC} \approx 87)$ due to tungsten carbides, ensures a decrease in the average power of AE by 2 times at the wear-in stage due to the implementation of structural adjustment by triboelement with less stress-deformed changes.

2. A decrease in the wear rate of 30 HGSA steel by 15 and 5.8 times for friction pairs D16+VK $8-$ $30 \mathrm{HGSA}$ and 30HGSA - D16+VK8 respectively, when duraluminium D16 is used as a counterface under friction with an electrospark coating of VK8 alloy, as compared with the unmodified surface D16.

3. An increase in the rate of wear of the movable modified surface of duralumin D16+VK 8 by 4.6 times (friction pair D16+VK8 - 30HGSA) and a decrease of this parameter by 300 times for a pair 30HGSA D16+VK8, where sample D16+VK8 was fixed.

4. Due to the growth of friction power 1.27 - 2 times in the process of structural adaptability of the contact surfaces with an electrospark coating, thermal activation of the surface metal layers is intensified and the dominant role of oxygen in the formation of wear-resistant secondary structures is manifested. 


\section{References}

1. Fan Y., Gu F., Ball A. Modelling acoustic emissions generated by sliding friction / Y. Fan, F. Gu, A. Ball // Wear, 2010, Vol. 268, Is. 5-6, P. 811-815.

2. Lingard S., Ng K.K. An investigation of acoustic emission in sliding friction and wear of metals / S. Lingard, K.K. Ng// Wear, 1989, Vol. 130, Is. 2., P. 367-379.

3. Benabdallah H. S., Aguilar D. A. Acoustic Emission and Its Relationship with Friction and Wear for Sliding Contact / H. S. Benabdallah, D. A. Aguilar // Tribology Transactions. - 2008. - Vol. 51, Is. 6, P. 738747.

4. Aljuminievye splavy. V kn.: Aviacija: Jenciklopedija / Gl. red. G. P. Svishhev. - M.: Nauch. izd-vo «Bol'shaja ros. jencikl.»: Centr. ajerogidrodinam. institut im. N. E. Zhukovskogo, 1994, 736 p.

5. Aleksandrov V. D. Poverhnostnoe uprochnenie aljuminievyh splavov / V. D. Aleksandrov: dis. ... dokt. tehn. nauk: 05.02.01 / V. D. Aleksandrov, Moskva, 2002, 410 p.

6. Jurchenko E.V., Jurchenko V.I., Dikusar A.I. Nanostrukturirovanie poverhnosti iz aljuminievyh splavov v uslovijah jelektroiskrovogo legirovanija / E.V. Jurchenko, V.I. Jurchenko, A.I. Dikusar // Nanoinzhenerija, 2013, No 2, pp.12-24.

7. Aljuminij i ego splavy: Uchebnoe posobie / Sost. A.R.Luc, A.A. Suslina. - Samara: Samar. gos. tehn. un-t, 2013, 81 p.

8. Uprochnenie poverhnostnogo sloja aljuminievogo splava $\mathrm{AMg} 6$ s pomoshh'ju kombinirovannoj jelektroiskrovoj i ul'trazvukovoj udarnoj obrabotki / G. I. Prokopenko, B. N. Mordjuk, V. F. Mazanko, N. A. Efimov, N. A. Piskun // Metallofizika i novejshie tehnologii, 2013, t. 35, No 10, pp. 1391-1406.

9. Stadnichenko V.N. Avtomatizirovannaja sistema tribodiagnostiki / V.N. Stadnichenko // Problemi tertja ta znoshuvannja, 2006, No 46, pp.51-63.

10. Filonenko S.F., Stadnychenko V.M. Definition of contact stress in friction units on the basis of the acoustic emission method / S.F.Filonenko, V.M. Stadnychenko // Aviation, 2009, Vol.13, No 3, pp.72-77.

11. Zakonomirnosti zmini tribotehnichnih parametriv ta signaliv akustichnoï emisiï dlja pari tertja 30HGSA - D16 / V.V. Tokaruk, O.O. Mikosjanchik, R.G. Mnacakanov, A.P. Kudrin // Problemi tertja ta znoshuvannja, 2019, No 2 (83), pp. 19-28.

12. Poverhnostnaja prochnost' materialov pri trenii / B.I. Kosteckij, I.G. Nosovskij, A.K. Karaulov i dr. / pod. obshh. ped. d.t.n. Kosteckij B.I. - K.: Tehnika, 1976, 296 p.

Мікосянчик О.О., Токарук В.В., Мнацаканов Р.Г. Оцінка триботехнічних характеристик та сигналів акустичної емісії для пари тертя сталі 30ХГСА та дюралюмінію Д16, модифікованого сплавом ВК8

Розглянуто застосування методу акустичної емісії для дослідження процесів структурної пристосованості при терті в умовах ковзання для трибосистеми сталі 30ХГСА та дюралюмінію Д16, на поверхню якого методом електроіскрового легування нанесено сплав ВК8 3 подальшою обробкою поверхні поверхневим пластичним деформуванням. Встановлено формування зносостійких вторинних структур за рахунок збільшення інтенсивності тепловиділення в фрикційному контакті, що призводить до зростання механо-хімічної активації поверхневих шарів металу. Модифікування дюралюмінію Д16 електроіскровим покриттям ВК8 забезпечує зниження усередненої потужності акустичної емісії в 2 рази на етапі припрацювання шляхом зменшення напружено-деформованого стану поверхневих шарів та зменшенні здатності матеріалу ВК-8 поглинати механічну енергію в процесі деформації. Встановлена кореляційна залежність загального вагового зносу пар тертя та усередненої потужності акустичної емісії.

Ключові слова: акустична емісія, знос, дюралюміній Д16, сплав ВК8, електроіскрове легування, структурна пристосованість. 